\title{
PROSES BERPIKIR LATERAL SISWA MADRASAH ALIYAH DALAM MENYELESAIKAN MASALAH GEOMETRI MELALUI PENDEKATAN OPEN- ENDED
}

\section{THE PROCESS OF LATERAL THINKING AMONGST THE STUDENTS IN MADRASAH ALIYAH IN SOLVING GEOMETRY PROBLEMS THROUGH OPEN-ENDED APPROACH}

\author{
Mukhtasar, M. Ikhsan, Hajidin \\ Prodi Magister Pendidikan Matematika FKIP Universitas Syiah Kuala Banda Aceh \\ Jl Tengku. Hasan Krueng Kalee, Darussalam, Banda Aceh \\ email: chay.tasar@gmail.com
}

Naskah Diterima: 21 September 2018; Direvisi: 17 Desember 2018; Disetujui: 25 Desember 2018

\begin{abstract}
This research aimed to describe the process of lateral thinking amongst the students in MAS (equivalent to Private Senior High School) Darul Hikmah, Aceh Besar in solving geometry problems through open-ended approach. This research was a descriptive research and conducted by using a qualitative approach. Research subject was three students of Class XII of MAS Darul Hikmah, Aceh Besar, who had different abilities. Subject selection was conducted at the end of the research. Data collection was carried out by conducting test and interview. Data analysis was done by using qualitative method, i.e.: data reduction, data display, and conclusion. The results showed that the process of lateral thinking amongst the students was: 1) writing and explaining the things being known and asked in the questions, 2) solving the problems by using different methods, 3) solving the problems by using unusual method as it was relatively short; did not use much math operation; and was easily to understand; and 4) getting the idea in solving the problems by practicing trial and error; using previous operations; using triangle and diagonal; and having the ability to explain the unusual steps that have been used.
\end{abstract}

Keywords: Geometry; Lateral thinking; Open-ended approach

\begin{abstract}
Abstrak
Penelitian ini bertujuan untuk mendeskripsikan proses berpikir lateral siswa siswa MAS Darul Hikmah Aceh Besar dalam menyelesaikan masalah geometri melalui pendekatan open-ended. Penelitian ini berbentuk deskriptif dengan pendekatan kualitatif. Subjek penelitian adalah tiga orang siswa kelas XII MAS Darul Hikmah Aceh besar yang memiliki kemampuan berbeda. Pemilihan subjek dilakukan pada akhir penelitian. Pengumpulan data dilakukan dengan tes dan wawancara. Analisis data menggunakan teknik analisis data kualitaif yaitu: reduksi data, penyajian data, dan penarikan kesimpulan. Hasil penelitian menunjukkan bahwa proses berpikir lateral siswa adalah: 1) menuliskan dan menyebutkan apa yang diketahui dan yang ditanyakan pada soal; 2) menyelesaikan permasalahan yang diberikan dengan mengunakan cara-cara penyelesaian berbeda; 3) menyelesaikan permasalahan dengan menggunakan cara yang tidak umum, lebih memilih menggunakan cara penyelesaiaan tidak umum karena relatif lebih singkat, tidak banyak menggunakan perhitungan matematika, dan mudah dipahami; dan 4) mendapatkan ide dalam menyelesaikan permasalahan dengan cara mencoba-coba, memanfaatkan cara penyelesaian yang pernah dikerjakan sebelumnya, memanfaatkan segitiga siku-siku, diagonal garis, dan mampu memberikan penjelasan mengenai langkah penyelesaian tidak umum yang telah digunakan.
\end{abstract}

Kata kunci: Berpikir lateral; Geometri; Pendekatan open-ended 


\section{PENDAHULUAN}

Metematika mempunyai peran sangat penting dalam kehidupan sehari-hari. Hampir semua ilmu membutuhkan matematika sebagai alat bantu, terutama ilmu-ilmu eksak. Matematika mempunyai tiga fungsi, yaitu 1) alat untuk memahami dan menyampaikan informasi, misalnya menggunakan tabel-tabel atau model-model matematika untuk menyederhanakan soal-soal cerita atau soalsoal uraian matematika; 2) upaya pembentukan pola pikir dalam pemahaman suatu pengertian maupun dalam penalaran suatu hubungan diantara pengertian-pengertian itu; dan 3) ilmu pengetahuan, dimana matematika senantiasa mencari kebenaran dan mencoba mengembangkan penemuan-penemuan dengan mengikuti tata cara yang tepat ${ }^{1}$. Dengan demikian, sudah seharusnya ketiga fungsi tersebut menjadi perhatian pada pengajaran matematika di sekolah.

Matematika membekali siswa untuk mempunyai kemampuan berpikir logis, analitis, sistematis, kritis, dan kreatif serta kemampuan bekerja sama ${ }^{2}$. Oleh sebab itu, matematika menjadi salah satu mata pelajaran penting yang harus dikuasai oleh setiap siswa. Matematika sebenarnya memiliki objek-objek kajian tertentu yang perlu untuk dipelajari. Objek kajian matematika yang terdiri dari fakta, konsep, operasi, dan prinsip merupakan hal-hal yang abstak sehingga untuk memahaminya tidak cukup hanya dengan menghafal, tetapi dibutuhkan adanya proses berpikir ${ }^{3}$. Dengan demikian, pembelajaran matematika sudah seharusnya memberikan penekanan pada proses berpikir siswa. Karena

${ }^{1}$ Suherman, E., Turmudi., Suryadi, D., Herman, T., Suhendra., Prabawanto, S., Nurjanah., \& Rohayati, A. (2003). Strategi Pembelajaran Matematika Kontemporer. Bandung: Jurusan Pendidikan Matematika Fakultas Pendidikan Matematika dan Ilmu Pendidikan Alam Universitas Pendidikan Indonesia.

${ }^{2}$ Tim Puspendik. (2012). Kemampuan Matematika Siswa SMP Indonesia: Menurut Bebchmark Internasional TIMSS 2011. Pusat Penelitian Pendidikan Badan Penelitian dan Pengembangan Kementrian Pendidikan dan Kebudayaan: Jakarta.

${ }^{3}$ Soedjadi. (2000). Kiat Pendidikan Matematika di Indonesia. Jakarta: Direktorat Jendral Pendidikan Tinggi Departemen Pendidikan Nasional. permasalahan yang mendasar dalam dunia pendidikan matematika adalah rendahnya kualitas dalam proses berpikir matematika ${ }^{4}$.

Fakta di lapangan menunjukkan bahwa para guru kurang melatih atau membiasakan proses berpikir dalam pembelajaran matematika. Pembelajaran matematika hanya terlihat sebagai suatu kegiatan yang monoton dan prosedural, yaitu guru menerangkan materi, memberikan contoh, menugaskan siswa untuk mengerjakan soal latihan, mengecek jawaban siswa secara sepintas, dan membahas pemecahan soal. Proses berpikir siswa yang merupakan aspek esensial dari pembelajaran seolah-olah diabaikan ${ }^{5}$. Padahal salah satu peran guru dalam pembelajaran matematika adalah membantu siswa mengungkapkan proses yang berjalan dalam pikirannya ketika menyelesaikan masalah matematika $^{6}$. Kondisi ini menyebabkan siswa menjadi kesulitan ketika memahami soal maupun dalam memecahkan masalah matematika. Sehingga tidak dapat dipungkiri bahwa anggapan yang saat ini berkembang pada sebagian besar siswa adalah matematika bidang studi yang sulit dan tidak disenangi. Hanya sedikit yang mampu memahami matematika sebagai ilmu yang dapat melatih kemampuan berpikir. Hal inilah yang menjadi salah satu faktor yang menyebabkan rendahnya nilai $\mathrm{UN}$ matematika $\mathrm{SMA}^{7}$.

Rendahnya hasil belajar siswa dapat dilihat salah satunya pada materi geometri yang merupakan salah satu bagian matematika yang paling memprihatinkan. Kesulitan siswa dalam mempelajari geometri

${ }^{4}$ Jazuli, A. 2009. Jigsaw Type of Cooperative Learning as a Means of Improving High SchoolStudents' Mathematical Communication Ability. EDUCARE, 1(2): 207-218.

${ }^{5}$ Ngilawajan, D, A. 2013. Proses Berpikir Siswa SMA dalam Memecahkan Masalah Matematika Materi Turunan Ditinjau dari Gaya Kognitif Field Independent dan Field Dependent. PEDAGOGIA, 1(1), 71-83.

${ }^{6}$ Yulaelawati, E. (2004). Kurikulum dan Pembelajaran. Bandung: Pakar Raya.

${ }^{7}$ Puspitarini, M. 2015. Ini penyebab Nilai Matematika Indonesia Rendah, https://news.okezone.com/read/2014/09/09/373/103650 6/ini-penyebab-nilai-matematika-indonesia-rendah, dikutip pada tanggal 9 September 2015. 
tentunya berdampak pada kemampuan pemahaman geometri siswa yang kurang sempurna, sehingga dapat menghambat pembelajaran geometri selanjutnya ${ }^{8}$. Hal ini sesuai dengan hasil studi pendahuluan yang telah peneliti lakukan pada Madrasah Aliyah Swasta (MAS) Darul Hikmah Aceh Besar. Ber-dasarkan hasil tes yang peneliti berikan pada 17 siswa, terlihat bahwa 7 siswa tergolong kategori rendah (41\%), 7 siswa kategori sedang (41\%), dan 3 siswa kategori tinggi (18\%). Hasil ini menunjukkan bahwa masih banyak siswa yang belum paham dengan materi geometri. Pada kenyataannya, tujuan pembelajaran geometri adalah agar siswa memperoleh rasa percaya diri mengenai kemampuan matematikanya, menjadi pemecah masalah yang baik, dapat berkomunikasi dan bernalar secara matematis ${ }^{9}$.

Salah satu cara yang dapat digunakan untuk membantu siswa dalam belajar geometri adalah dengan melatih berpikir lateral. Apabila suatu pemecahan masalah ingin diperoleh melalui berpikir lateral, maka selalu terdapat suatu jalur yang logis yang digunakan untuk memperoleh pemecahan itu. Oleh karena itu, apa yang dianggap sebagai berpikir lateral adalah tidak lain dari suatu himbauan untuk berpikir logis dengan lebih baik $^{10}$. Inti dari berpikir lateral (lateral thinking) adalah banyak masalah yang membutuhkan perspektif atau pandangan berbeda.

Berpikir lateral penting diterapkan di Madrasah Aliyah, terutama MAS Darul Hikmah Aceh Besar demi terwujudnya siswa berkualitas, unggul dalam prestasi, cerdas dalam berfikir, mandiri, dan berakhlakul karimah. Hal ini dikarenakan berpikir lateral dapat membantu siswa dalam mengubah persepsi yang umum dipakai kepersepsi yang

${ }^{8}$ Nurhasanah, F. 2010. Abstraksi Siswa SMP dalam Belajar Geometri melalui Penerapan Model Van Hiele dan Geometers Sketchpad. Thesis, Universitas Pendidikan Indonesia. hal 4

${ }^{9}$ Bobango, J. C. (1993). Geometry for All Student: Phase-Based Instruction. Dalam Cuevas (Eds). Reaching All Students With Mathematics. Virginia: The National Council of Teachers of Mathematics, Inc.

${ }^{10}$ Bono, E. D. (1991). Penerapan Pola Berpikir Lateral (terjemahan Dandan Riskomar) Jakarta: Binarupa Aksara. berbeda dalam penyelesaian masalah. Pendapat tersebut mengisyaratkan bahwa berpikir lateral merupakan salah satu langkah untuk berpikir secara lebih terbuka, fleksibel, dan kreatif terhadap suatu masalah ${ }^{11}$. Hal ini tentu sesuai dengan salah satu tujuan pendidikan Islam yaitu peningkatan kualitas pembelajaran yang berorientasi pada pembentukan karakter peserta didik ${ }^{12}$. Dengan demikian berpikir lateral dapat membuka jalan untuk membentuk pola berpikir dan menghasilkan ide-ide baru ${ }^{13}$. Berpikir lateral berhubungan erat dengan kreativitas. Namun, apabila kreativitas seringkali hanya merupakan deskripsi suatu hasil, maka berpikir lateral merupakan deskripsi suatu proses ${ }^{14}$.

Berpikir lateral dapat digunakan untuk melatih kemampuan geometri siswa. Hal ini dikarenakan kemampuan berpikir lateral ini sangat ditunjang oleh kekuatan imajinasi dan inspirasi. Cara berpikir yang selama ini terlalu kaku dan konservatif, tentu sulit melihat kemungkinan dan realita lain yang sering dijumpai. Itulah sebabnya, orang yang kemampuan berpikir lateralnya bagus, akan mudah memahami konsep yang bersifat multidimensi dan melahirkan karya innovatif 15. Selain itu, berpikir lateral juga dapat memaksimalkan semua kemampuan alami yang dimiliki oleh siswa untuk mencari ide atau suatu penyelesaian yang baru tanpa harus takut salah maupun benar ${ }^{16}$.

Melatih berpikir lateral dalam pembelajaran matematika dilakukan dengan

\footnotetext{
${ }^{11}$ Syutaridho. 2012. Berpikir Lateral dalam Matematika. ISSN 2089-8703, 1(1), 22-29.

${ }^{12}$ Direktorat Jenderal Pendidikan Islam Kementerian Agama RI. Visi, Misi dan Tujuan Pendidikan Islam 2015-2019. http://pendis.kemenag. go.id/index.php?a=artikel\&id2=visimisipendis, dikutip pada tanggal 14 Desember 2018.

${ }^{13}$ Waks, S. 1997. Lateral Thinking and Technology Education. Journal of Science Education and Technology, 6(4): 245-255.

${ }^{14}$ Sloane, P. (1994). Test Your Lateral Thinking $I Q$. New York: Sterling Publishing Company, Inc.

${ }^{15}$ Suprapti, W. (2015). Bahan Ajar Diklat Kepemimpinan Tingkat 3: Agenda Inovasi. Lembaga Administrasi Negara Republik Indonesia: Jakarta

${ }^{16}$ Sa'diyah, H. 2016. Profil Berpikir Lateral dalam Menyelesaikan Masalah Matematika Materi Bangun Datar pada Siswa Kelas IX di SMP Negeri 1 Sidoarjo. Thesis, UIN Sunan Ampel Surabaya. hal 3
} 
selalu memberi kebebasan berpikir pada siswa, sehingga siswa dapat menganalisa dari bebagai sudut pandang. Keterampilan berpikir tidak dapat diperoleh siswa begitu saja tanpa diupayakan oleh guru. Pemberian kebebasan berpikir yang disertai bimbingan akan mengupayakan terwujudnya keterampilan berpikir siswa. Kegitan ini sangat baik dilakukan dalam pembelajaran kelompok agar siswa satu dengan lainnya memiliki keberagaman berpikir, sehingga membuka mata bagi seluruh siswa tentang cara berpikir 17.

Melatih berpikir lateral dapat dilakukan dengan memberikan permasalahan bersifat terbuka. Hal ini disebabkan karena berpikir lateral bukanlah keterampilan yang tidak jelas, tetapi adalah kekuatan laten (terpendam) yang dimiliki oleh setiap orang yang dapat dikembangkan dengan latihan, perubahan sikap mental dan pendekatan yang mengarah pada pemikiran terbuka pada suatu masalah ${ }^{18}$. Selain itu pembelajaran terbuka atau yang sering disebut dengan pendekatan open-ended dapat memberi kesempatan kepada siswa untuk memperoleh pengetahuan/pengalaman dalam menemukan sesuatu, mengenali, dan memecahkan masalah dengan beberapa teknik $^{19}$. Tujuan utama pemberian masalah open-ended kepada siswa adalah bukan untuk mendapatkan jawaban tetapi lebih menekankan pada cara bagaimana sampai pada suatu jawaban ${ }^{20}$. Dengan demikian bukanlah hanya satu cara dalam mendapatkan jawaban, namun beberapa atau banyak, sehingga dengan memberikan soal matematika yang sifatnya non rutin dan terbuka dapat mengoptimalkan berpikir lateral siswa ${ }^{21}$. Dengan demikian

\footnotetext{
${ }^{17}$ Rosnawati, R. 2011. Berpikir Lateral Dalam Pembelajaran Matematika. Prosiding Seminar Nasional Penelitian, Pendidikan dan Penerapan MIPA, 139-144. Fakultas MIPA, Universitas Negeri Yogyakarta: Prosiding Seminar Nasional Penelitian, Pendidikan dan Penerapan MIPA.

${ }^{18}$ Sloane, P, Op. Cit., hal 34

${ }^{19}$ Becker, J. P., \& Shimada, S. (2005). The Open-Ended Approach: A New Proposal for Teaching. Reston: National Council of Teachers of Mathematic (NCTM).

${ }^{20}$ Suherman, E, et all, Op. Cit., hal 3

${ }^{21}$ Muliawati, N. E. 2017. Proses Berpikir Lateral Siswa dalam Memecahkan Masalah Berdasarkan Gaya
}

pembelajaran matematika dengan pendekatan open-ended dapat menunjukkan sikap positif terhadap pembelajaran matematika dan peningkatan kemampuan berpikir lateral siswa $^{22}$.

Contoh penerapan pendekatan openended dalam kegiatan pembelajaran adalah ketika siswa diminta mengembangkan metode atau cara yang berbeda dalam menjawab permasalahan yang diberikan dan bukan berorientasi pada jawaban (hasil) akhir. Pola pikir siswa harus dikembangkan semaksimal mungkin sesuai dengan kemampuan setiap siswa. Selain itu, dengan diberikan masalah yang bersifat terbuka, siswa terlatih untuk melakukan investigasi berbagai strategi dalam menyelesaikan masalah. Selain itu siswa akan memahami bahwa proses penyelesaian suatu masalah sama pentingnya dengan hasil akhir yang diperoleh ${ }^{23}$. Dengan demikian, pendekatan open-ended dapat memberi kesempatan kepada siswa untuk berpikir bebas sesuai dengan minat dan kemampuannya sehingga kemampuan berpikir siswa dapat berkembang secara maksimal dan kegiatan-kegiatan kreatif siswa dapat terkomunikasikan melalui proses pembelajaran.

Penelitian yang telah dilakukan oleh Syutaridho (2012) dan Sa'diyah (2016) mengidentifikasikan bahwa siswa dapat menyelesaikan permasalahan yang diberikan dengan menggunakan berbagai alternatif penyelesaian. Namun, kedua penelitian tersebut dilakukan tanpa memberikan pembelajaran yang dapat melatih siswa dalam berpikir lateral dengan menggunakan pendekatan tertentu. Selain itu, Sa'diyah (2016) juga menyarankan peneliti selanjutnya untuk melakukan penelitian pada SMA/MA sederajat, sehingga bisa mendapatkan data berpikir lateral siswa yang lebih luas, lebih mendalam dan variatif. Dengan demikian, yang menjadi rumusan masalah pada penelitian ini adalah bagaimana proses

Kognitif dan Gender. Jurnal Pendidikan dan Pembelajaran Matematika (JP2M), 2(1): 55-68.

${ }^{22}$ Nurhidayah, S. D. (2016). Meningkatkan Kemampuan Berpikir Lateral Matematis Siswa melalui Pendekatan Open-Ended. Thesis, Universitas Pendidikan Indonesia. hal 5

${ }^{23}$ Becker, J. P., \& Shimada, S, Op. Cit., hal 3 
berpikir lateral siswa MAS Darul Hikmah Aceh Besar dalam menyelesaikan masalah geometri melalui pendekatan open-ended ?

Berdasarkan rumusan masalah tersebut, maka yang menjadi tujuan dari penelitian ini adalah mendeskripsikan proses berpikir lateral siswa siswa MAS Darul Hikmah Aceh Besar dalam menyelesaikan masalah geometri melalui pendekatan open-ended.

\section{METODOLOGI PENELITIAN}

Penelitian ini menggunakan jenis penelitian deskriptif, yaitu penelitian yang bertujuan untuk menjelaskan atau mendeskripsikan suatu keadaan, peristiwa, objek, atau sesuatu yang terkait dengan variabel-variabel yang bisa dijelaskan baik dengan angka-angka maupun dengan katakata. Dengan kata lain, penelitian ini bertujuan untuk mendeskripsikan proses berpikir lateral siswa dalam menyelesaikan masalah geometri melalui pendekatan openended. Pendekatan yang digunakan dalam peneltian ini adalah pendekatan kualitatif, karena penelitian ini mengembangkan konsep atas data yang ada yaitu lebih mementingkan proses daripada hasil ${ }^{24}$.

Penelitian ini dilakukan pada MAS Darul Hikmah Aceh Besar semester ganjil tahun ajaran 2017/2018. Alasan peneliti memilih sekolah tersebut adalah berdasarkan observasi awal yang dilakukan sebelumnya, bahwa banyak siswa yang mengalami kesulitan dalam menyelesaikan soal-soal geometri. Selain itu, sekolah MAS Darul Hikmah Aceh Besar juga masih tergolong baru sehingga pihak sekolah mengharapkan adanya pembelajaran dengan pendekatanpendekatan tertentu untuk membantu siswa dalam belajar. Setelah melakukan pembelajaran selama tiga kali pertemuan dan tes pada setiap akhir peembelajaran, dipilihlah tiga orang subjek penelitian yang masingmasing memiliki kemampuan tinggi, sedang, dan rendah. Pembagian tinggi, sedang, dan rendah ini berdasarkan nilai rapor matematika pada semester genap tahun ajaran 2016/2017.

${ }^{24}$ Moleong, L. J. (2016). Metodologi Penelitian Kualitatif. Edisi Revisi. Bandung: PT Remaja Rosdakarya.
Alasan pembagian kategori ini karena peneliti ingin memperoleh data proses berpikir lateral siswa dari berbagai kemampuan dan tidak hanya berfokus pada satu kemampuan saja.

Pengumpulan data dalam penelitian ini menggunakan teknik tes dan wawancara. Teknik tes digunakan untuk mengumpulkan data proses berpikir lateral siswa. Teknik wawancara digunakan untuk menemukan data yang tidak ditemukan pada tes dan untuk memastikan apa dikatakan subjek penelitian sama dengan apa yang telah dikerjakan.

Instrumen penelitian berupa soal tes dan pedoman wawancara. Soal tes yang digunakan berbentuk open-ended mengarah pada banyak cara penyelesaian. Pengukuran proses berpikir lateral siswa dilakukan didasarkan pada aspek berpikir lateral siswa yaitu: 1) mengetahui ide pokok dari masalah yang sedang dihadapi, 2) mencari cara-cara alternatif dalam memandang permasalahan, 3) melonggarkan kendali cara berpikir yang kaku, dan 4) menggunakan ide-ide acak untuk membangkitkan ide-ide baru ${ }^{25}$.

Aspek berpikir lateral dalam penelitian ini dikembangkan menjadi empat indikator. Keempat indikator berpikir lateral siswa dalam penelitian ini dapat dilihat pada Tabel 1 .

Teknik analisis data yang digunakan dalam penelitian ini yaitu menggunakan teknik analisis kualitatif yaitu: reduksi data (data reduction), penyajian data (data display), dan penarikan kesimpulan (conclution drawing) ${ }^{26}$. Langkah-langkah analisis data dalam penelitian ini sebagai berikut.

Pertama Reduksi Data (data reduction). Reduksi data adalah bentuk analisis yang bertujuan untuk mempertajam, menyoroti, menfokuskan, membuang, dan mengatur data, sedemikian sehingga data tersebut dapat ditarik suatu kesimpulan atau diverifikasi. Aktivitas yang dilakukan dalam reduksi data adalah merangkum data hasil tes dan

25 Syutaridho. (2012). Berpikir Lateral dalam Matematika. ISSN 2089-8703, 1(1): 22-29.

26 Miles, M. B., \& Huberman A, M. (1994). Qualilative Data Analysis: Second Edition. United States of America: Sage Publications. 
wawancara, melakukan penyelesaian, memfokuskan penyederhanaan, dan mentransformasikan kembali data mentah yang diperoleh di lapangan.

Kegiatan peneliti pada tahap ini adalah (a) Mentranskipkan seluruh ucapan siswa dengan memutar kembali rekaman wawancara; (b) Menyeleksi rekaman wawancara dengan membuang bagian-bagian yang tidak diperlukan; (c) Memeriksa kembali kebenaran hasil transkipsi dengan memutar kembali rekaman hasil wawancara sampai benar-benar jelas apa yang diungkapkan oleh subjek dalam wawancara; (d) Membuat kode yang sesuai untuk subjek penelitian; (e) Mengetik dan menyusun hasil transkipsi agar memudahkan proses analisis.

Kedua Tahap penyajian data (data display). Penyajian data mencakup penyusunan dan pengorganisasian data yang berhasil dikumpulkan selama penelitian sehingga dapat terorganisasi dengan baik dan bermakna dengan tujuan untuk memudahkan penarikan kesimpulan. Data yang telah disajikan dapat memudahkan peneliti dalam menguasai dan memahami data tersebut sebagai dasar dalam mengambil kesimpulan yang tepat.

Pada tahap ini, peneliti menyajikan data yang merupakan hasil reduksi. Data proses berpikir lateral siswa Madrasah Aliyah dalam menyelesaikan masalah geometri melalui pendekatan open-ended dikategorikan dan disajikan dalam bentuk teks naratif berdasarkan kemampuan kognitif dari masing-masing siswa. Penyajian data ini mendeskripsikan hasil tes dan wawancara.

Tabel 1. Aspek dan Indikator Kemampuan Berpikir Lateral

\begin{tabular}{|c|l|l|}
\hline No & Aspek-aspek Berpikir Lateral & \multicolumn{1}{|c|}{ Indikator Berpikir Lateral } \\
\hline 1 & $\begin{array}{l}\text { Mengetahui ide pokok dari } \\
\text { masalah yang sedang dihadapi }\end{array}$ & $\begin{array}{l}\text { Mengidentifikasi unsur-unsur yang diketahui pada } \\
\text { sal. } \\
\text { Ciri-cirinya: menyatakan apa yang diketahui dan } \\
\text { yang ditanyakan pada soal. }\end{array}$ \\
\hline 2 & $\begin{array}{l}\text { Mencari cara-cara alternatif } \\
\text { dalam memandang permasalahan }\end{array}$ & $\begin{array}{l}\text { Menyelesaikan permasalahan dengan lebih dari satu } \\
\text { cara. } \\
\text { Ciri-cinya: dapat menggunakan lebih dari satu cara } \\
\text { penyelesaian }\end{array}$ \\
\hline 3 & $\begin{array}{l}\text { Melonggarkan kendali cara } \\
\text { berpikir yang kaku }\end{array}$ & $\begin{array}{l}\text { Menyelesaikan permasalahan dengan cara yang tidak } \\
\text { umum. } \\
\text { Ciri-cirinya: } \\
\text { - dapat menyelesaikan permasalahan dengan cara } \\
\text { yang tidak umum } \\
\text { memilih untuk menggunakan cara penyelesaian } \\
\text { yang tidak umum } \\
\text { dapat memberikan alasan mengapa memilih } \\
\text { menggunakan cara penyelesaian yang tidak umum }\end{array}$ \\
\hline 4 & $\begin{array}{l}\text { Menggunakan ide-ide acak untuk } \\
\text { membangkitkan ide-ide baru }\end{array}$ & $\begin{array}{l}\text { Mengunakan langkah-langkah penyelesaian berbeda } \\
\text { untuk menemukan jawaban yang benar. } \\
\text { Ciri-cinya: } \\
\text { dapat memberikan penjelasan mengenai cara } \\
\text { memperoleh ide dalam menyusun langkah } \\
\text { penyelesaian yang tidak umum } \\
\text { dapat memberikan penjelasan secara rinci } \\
\text { mengenai langkah penyelesaian tidak umum yang } \\
\text { telah digunakan }\end{array}$ \\
\hline
\end{tabular}


Ketiga Penarikan kesimpulan (conclution drawing). Setelah melakukan penyajian data, maka tahap selanjutnya adalah penarikan kesimpulan. Penarikan kesimpulan pada penelitian ini mengacu pada kriteria bentuk pengujian masalah yang diajukan. Penarikan kesimpulan bertujuan untuk mendeskripsikan proses berpikir lateral siswa Madrasah Aliyah dalam menyelesaikan masalah geometri melalui pendekatan openended.

Pengecekan keabsahan data pada penelitian ini menggunakan triangulasi sumber. Hal ini dilakukan karena peneliti ingin menemukan kesesuaian data yang diperoleh dari sumber yang berbeda. Pada

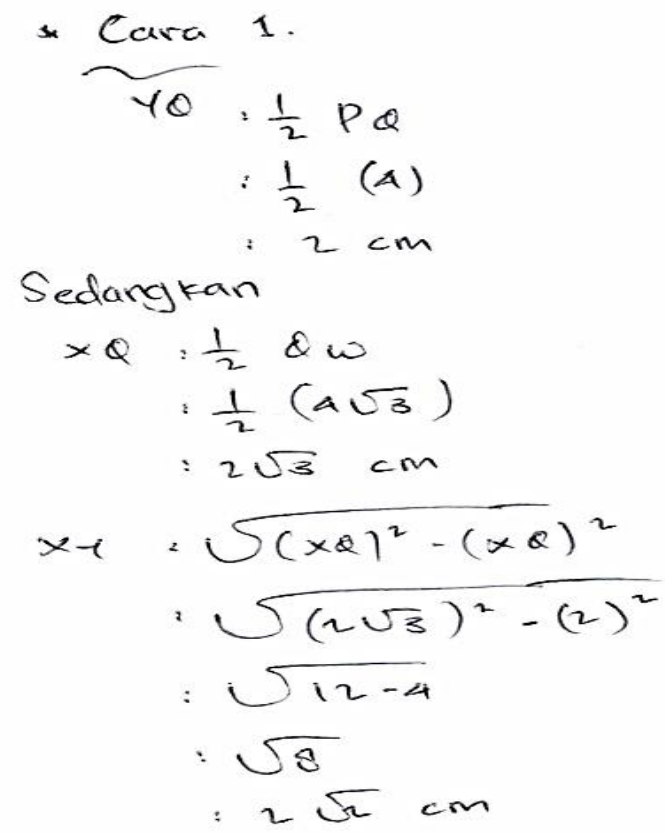

Gambar 1. Cara pertama subjek $A$ pada $T_{1}$

Subjek $A$ tidak menuliskan apa yang diketahui dan ditanyakan pada soal, namun tetap menyebutkannya secara lisan. Subjek $A$ juga dapat menyelesaikan permasalahan yang diberikan dengan menggunakan dua cara berbeda. Cara pertama termasuk cara yang umum dan kedua tidak umum. Subjek $A$ lebih memilih menggunakan cara yang tidak umum karena cara ini relatif lebih singkat dan tidak terlalu banyak menggunakan perhitungan matematika. Selain itu subjek $A$ juga dapat menjelaskan mengenai ide yang diperoleh penelitian ini, triangulasi sumber dilakukan pada guru bidang studi pendidikan matematika

\section{HASIL DAN PEMBAHASAN}

HASIL

\section{Proses Berpikir Lateral Siswa Berkemampuan Tinggi (Subjek A)}

Subjek $A$ tidak menuliskan apa yang diketahui dan yang ditanyakan pada soal dan subjek $A$ juga mampu menyelesaikan permasalah pada $T_{1}$ dengan dua cara berbeda. Berikut berikut lembar jawaban $A T_{1}$.

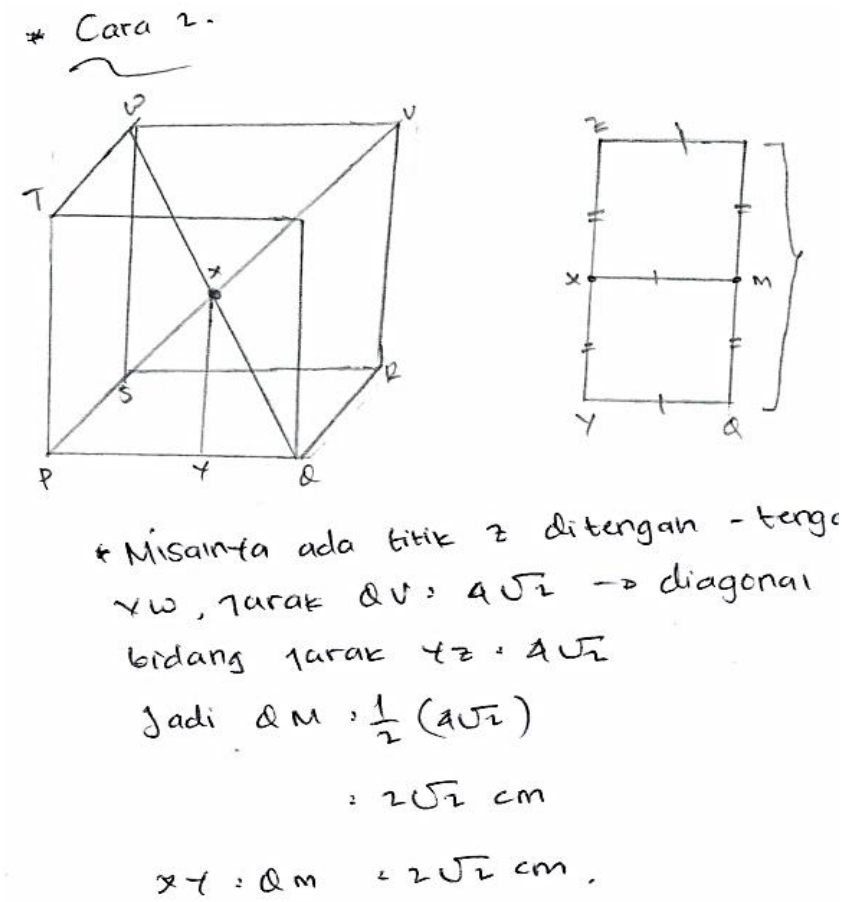

Gambar 2. Cara kedua subjek $A$ pada $T_{1}$

dalam menyusun cara menyelesaian yang tidak umum dan juga dapat menjelaskan secara rinci mengenai langkah-langkah penyelesaian tidak umum yang telah dikerjakan pada $T_{1}$.

Pada $T_{2}$, subjek $A$ tidak menuliskan apa yang diketahui dan yang ditanyakan pada soal dan subjek $A$ juga mampu menyelesaikan permasalah pada $T_{2}$ dengan dua cara berbeda. Berikut lembar jawaban $A T_{2}$. 


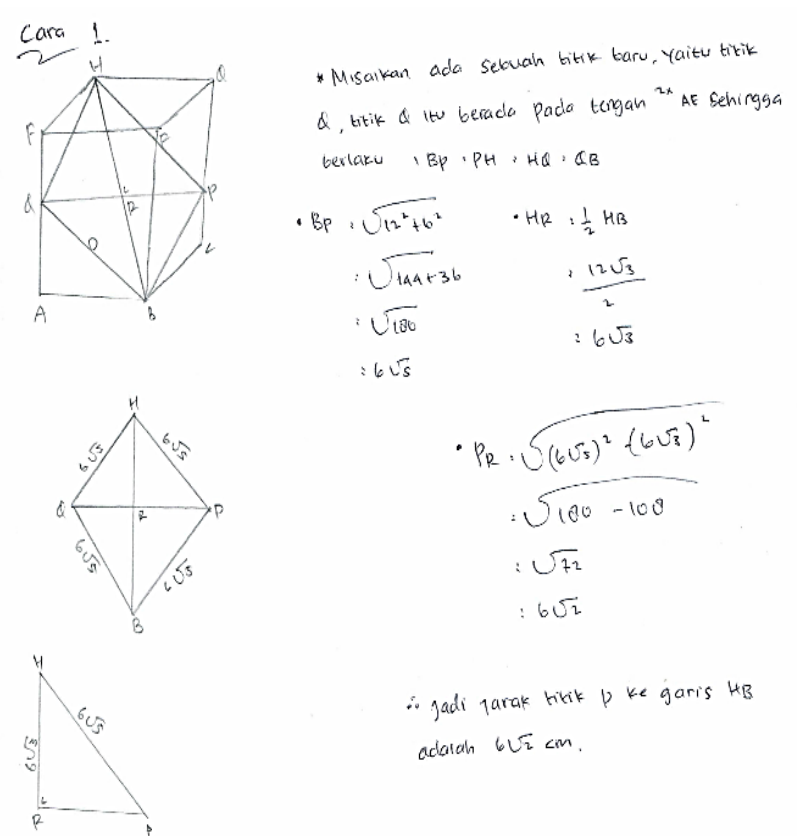

Gambar 3. Cara pertama subjek $A$ pada $T_{2}$

Subjek $A$ tidak menuliskan apa yang diketahui dan ditanyakan pada soal, namun tetap menyebutkannya secara lisan. Subjek $A$ juga dapat menyelesaikan permasalahan yang diberikan dengan menggunakan dua cara berbeda. Kedua cara penyelesaian ini termasuk cara yang tidah umum. Subjek $A$ lebih memilih menggunakan cara penyelesaian tidak umum kedua karena cara ini relatif lebih singkat. Selain itu subjek $A$ juga dapat menjelaskan mengenai ide yang

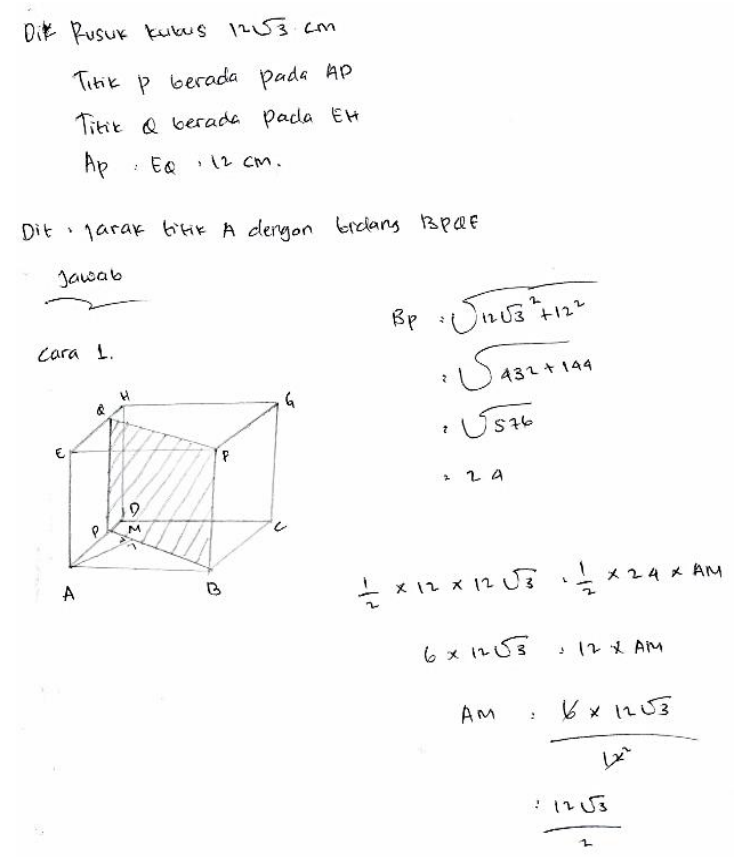

Gambar 5. Cara pertama subjek $A$ pada $T_{3}$

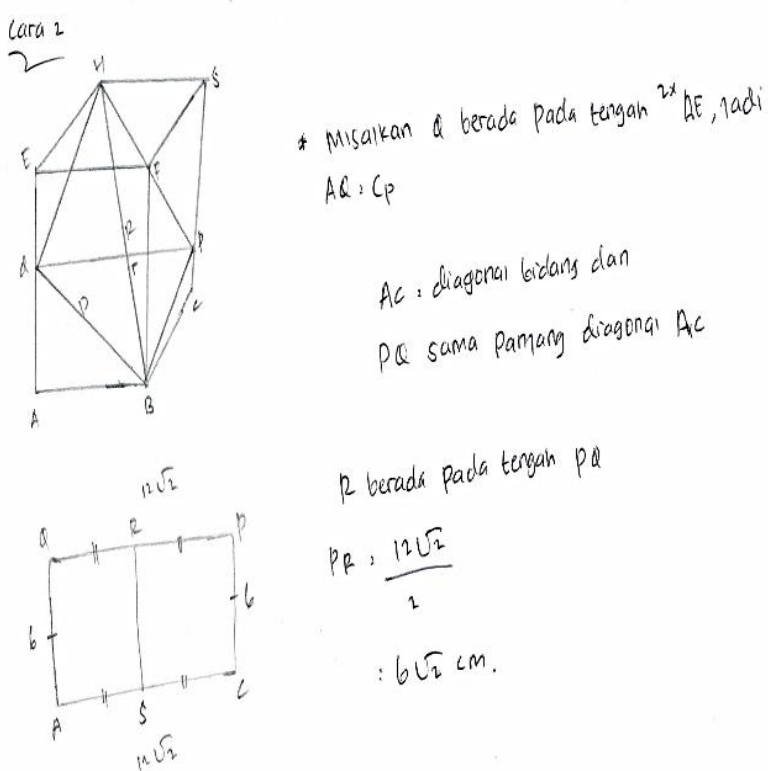

Gambar 4. Cara kedua subjek $A$ pada $T_{2}$

diperoleh dalam menyusun cara menyelesaian yang tidak umum dan juga dapat menjelaskan secara rinci mengenai langkah-langkah penyelesaian tidak umum yang telah dikerjakan pada $T_{2}$.

Pada $T_{3}$, subjek $A$ telah menuliskan apa yang diketahui dan yang ditanyakan pada soal dan subjek $A$ juga mampu menyelesaikan permasalah pada $T_{3}$ dengan dua cara berbeda. Berikut berikut lembar jawaban $A T_{3}$.
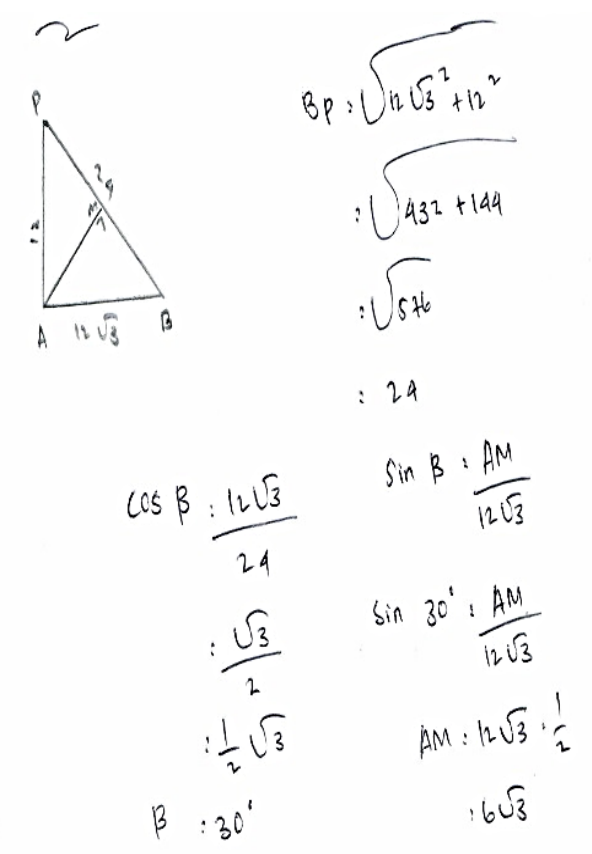

Gambar 6. Cara kedua subjek $A$ pada $T_{3}$ 
Subjek $A$ telah menuliskan dan dapat menyebutkannya apa yang diketahui dan ditanyakan pada secara lisan. Subjek $A$ juga dapat menyelesaikan permasalahan yang diberikan dengan menggunakan dua cara berbeda. Cara pertama termasuk cara yang umum dan kedua tidak umum. Subjek $A$ lebih memilih menggunakan cara yang tidak umum karena cara ini relatif lebih singkat, tidak terlalu banyak menggunakan perhitungan matematika, dan mudah untuk dipahami. Selain itu subjek $A$ juga dapat menjelaskan mengenai ide yang diperoleh dalam

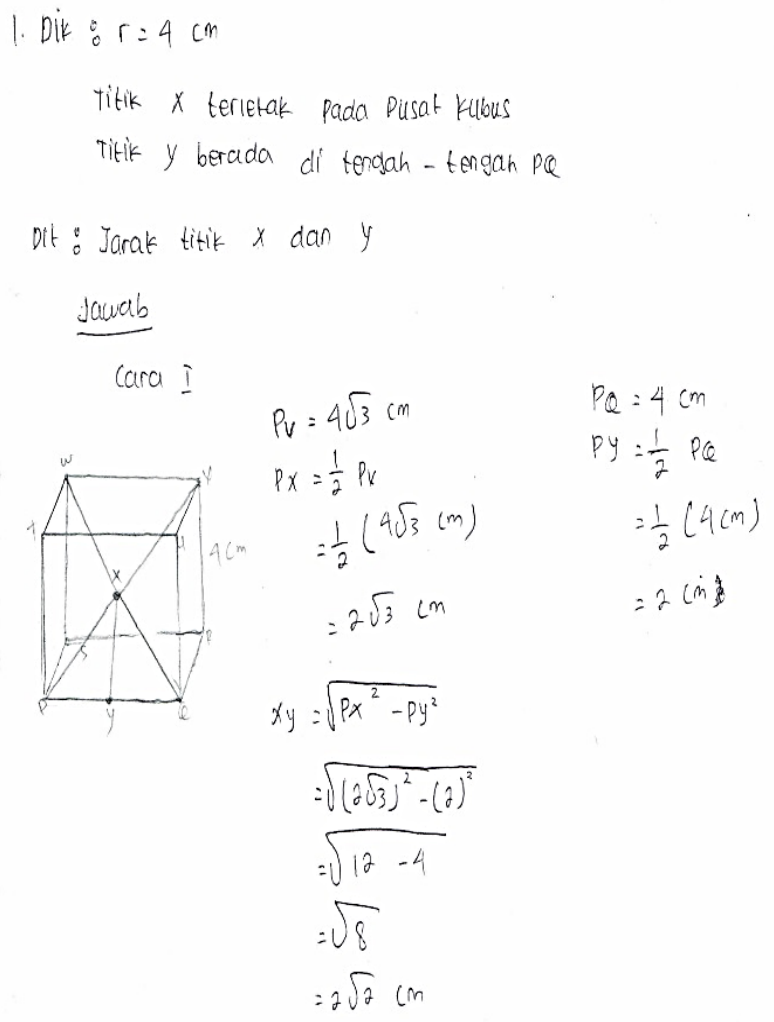

Gambar 7. Cara Pertama subjek $B$ pada $T_{1}$

Subjek $B$ telah menuliskan dan dapat menyebutkannya apa yang diketahui dan ditanyakan pada secara lisan. Subjek $B$ juga dapat menyelesaikan permasalahan yang diberikan dengan menggunakan dua cara berbeda. Cara pertama termasuk cara yang umum dan kedua tidak umum. Subjek $B$ lebih memilih menggunakan cara yang tidak umum karena cara ini relatif lebih singkat. Selain itu subjek $B$ juga dapat menjelaskan mengenai ide yang diperoleh dalam menyusun cara menyusun cara menyelesaian yang tidak umum dan juga dapat menjelaskan secara rinci mengenai langkah-langkah penyelesaian tidak umum yang telah dikerjakan pada $T_{3}$.

\section{Proses Berpikir Lateral Siswa Berkemampuan Sedang (Subjek B)}

Subjek $B$ telah menuliskan apa yang diketahui dan yang ditanyakan pada soal dan subjek $B$ juga mampu menyelesaikan permasalah pada $T_{1}$ dengan dua cara berbeda. Berikut berikut lembar jawaban $B T_{1}$.

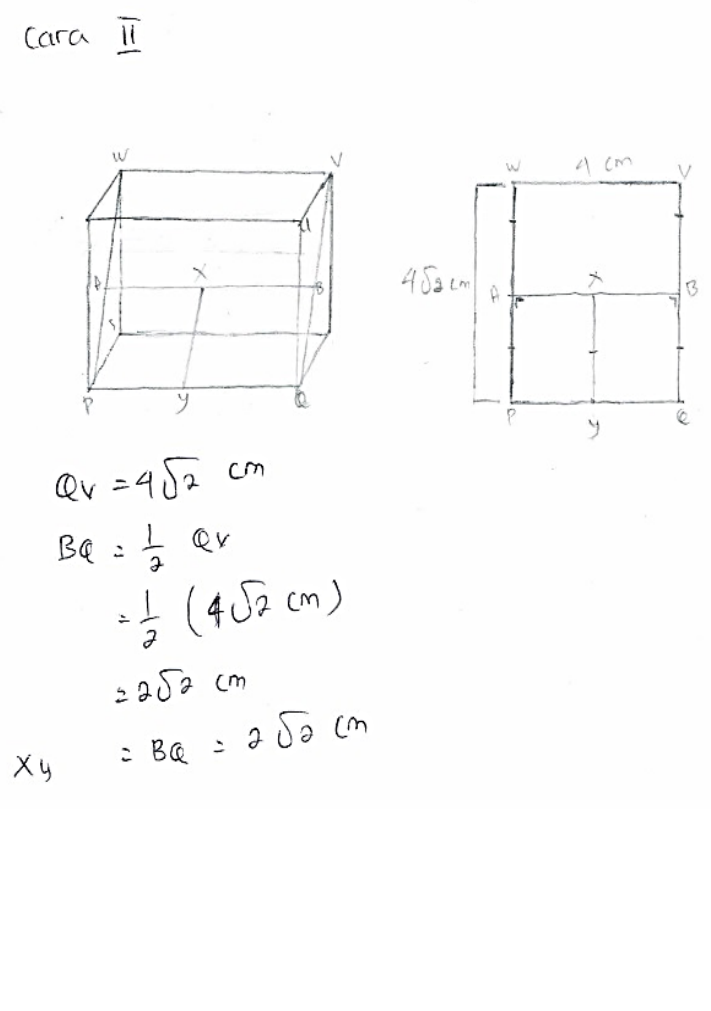

Gambar 8. Cara Kedua subjek $B$ pada $T_{1}$

menyelesaian yang tidak umum dan juga dapat menjelaskan secara rinci mengenai langkah-langkah penyelesaian tidak umum yang telah dikerjakan pada $T_{3}$.

Pada $T_{2}$, subjek $B$ tidak menuliskan apa yang diketahui dan yang ditanyakan pada soal dan subjek $B$ juga mampu menyelesaikan permasalah pada $T_{2}$ dengan dua cara berbeda. Berikut berikut lembar jawaban $B T_{2}$. 


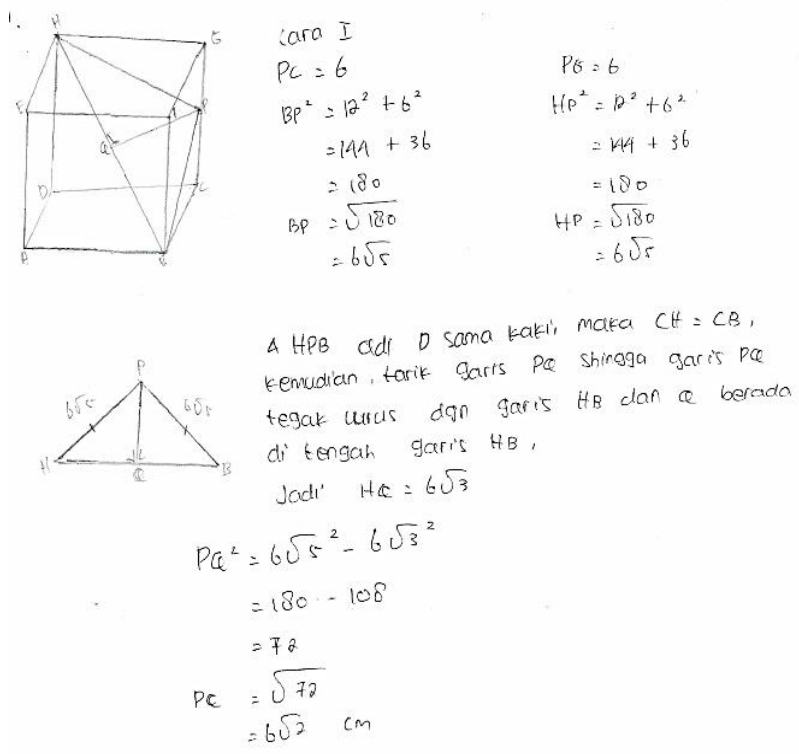

Gambar 9. Cara pertama subjek $B$ pada $T_{2}$

Subjek $B$ tidak menuliskan apa yang diketahui dan ditanyakan pada soal, namun tetap menyebutkannya secara lisan. Subjek $B$ juga dapat menyelesaikan permasalahan yang diberikan dengan menggunakan dua cara berbeda. Cara pertama termasuk cara yang umum dan kedua tidak umum. Subjek $A$ lebih memilih menggunakan cara yang tidak umum karena cara ini relatif lebih singkat. Selain itu subjek $A$ juga dapat menjelaskan mengenai ide yang diperoleh dalam menyusun cara

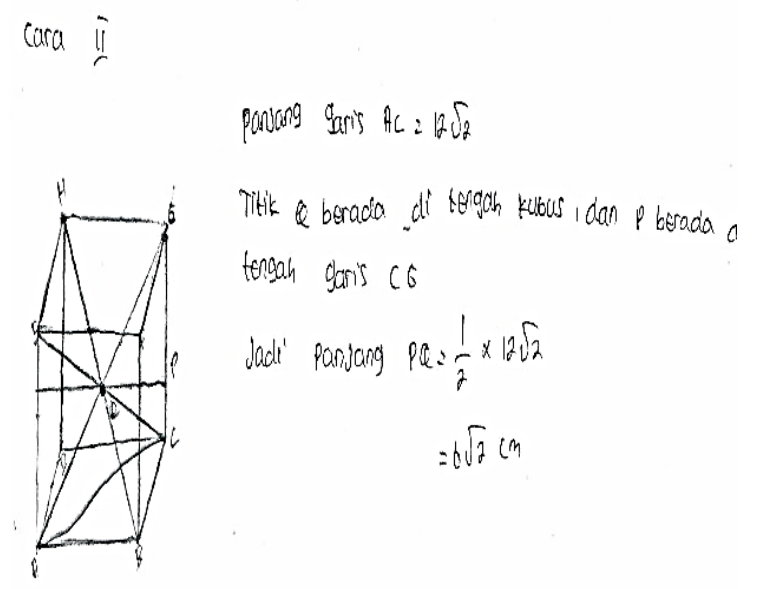

Gambar 10. Cara kedua subjek $B$ pada $T_{2}$

menyelesaian yang tidak umum dan juga dapat menjelaskan secara rinci mengenai langkah-langkah penyelesaian tidak umum yang telah dikerjakan pada $T_{2}$.

Pada $T_{3}$, subjek $B$ telah menuliskan apa yang diketahui dan yang ditanyakan pada soal dan subjek $B$ juga mampu menyelesaikan permasalah pada $T_{3}$ hanya dengan cara. Berikut lembar jawaban $B T_{3}$.

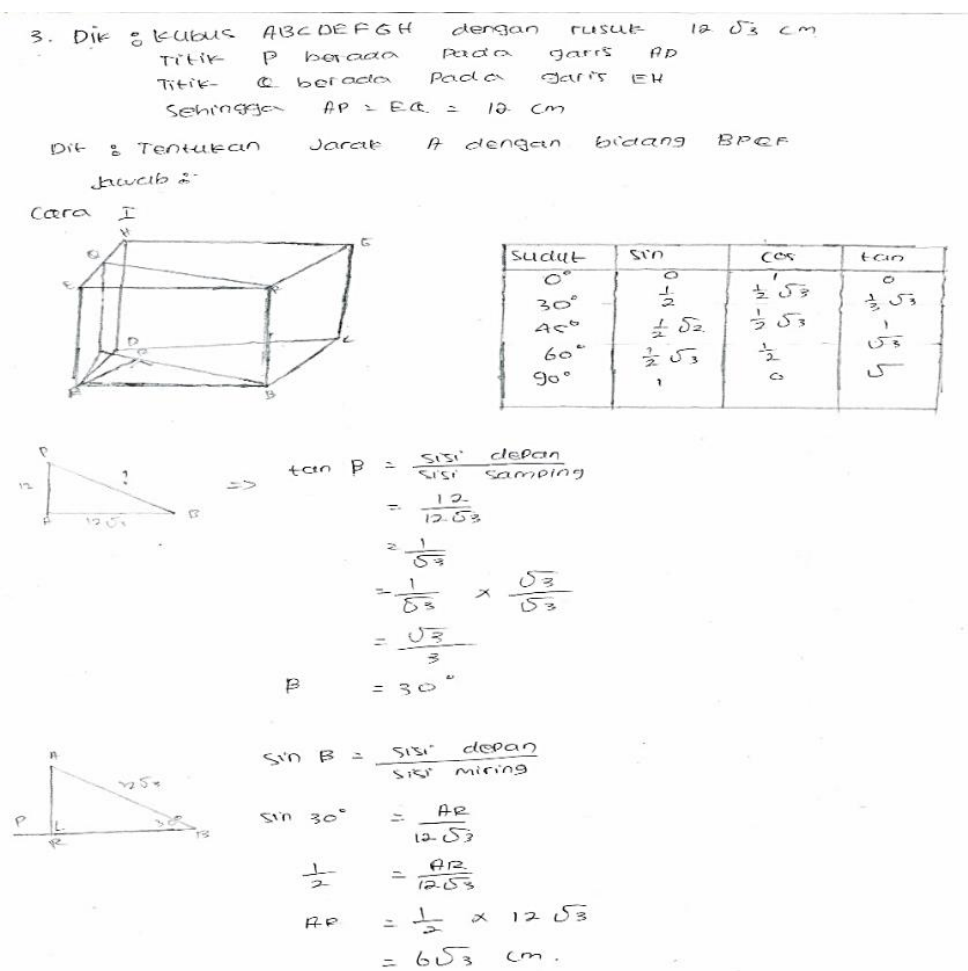

Gambar 11. Cara penyelesaian subjek $B$ pada $T_{3}$ 
Subjek $B$ tidak menuliskan apa yang diketahui dan ditanyakan pada soal, namun tetap menyebutkannya secara lisan. Subjek $B$ menyelesaikan permasalahan yang diberikan hanya dengan menggunakan satu cara, dan cara ini termasuk cara penyelesaian yang tidak umum. Selain itu subjek $B$ juga dapat menjelaskan mengenai ide yang diperoleh dalam menyusun cara menyelesaian yang tidak umum dan juga dapat menjelaskan secara rinci mengenai langkah-langkah

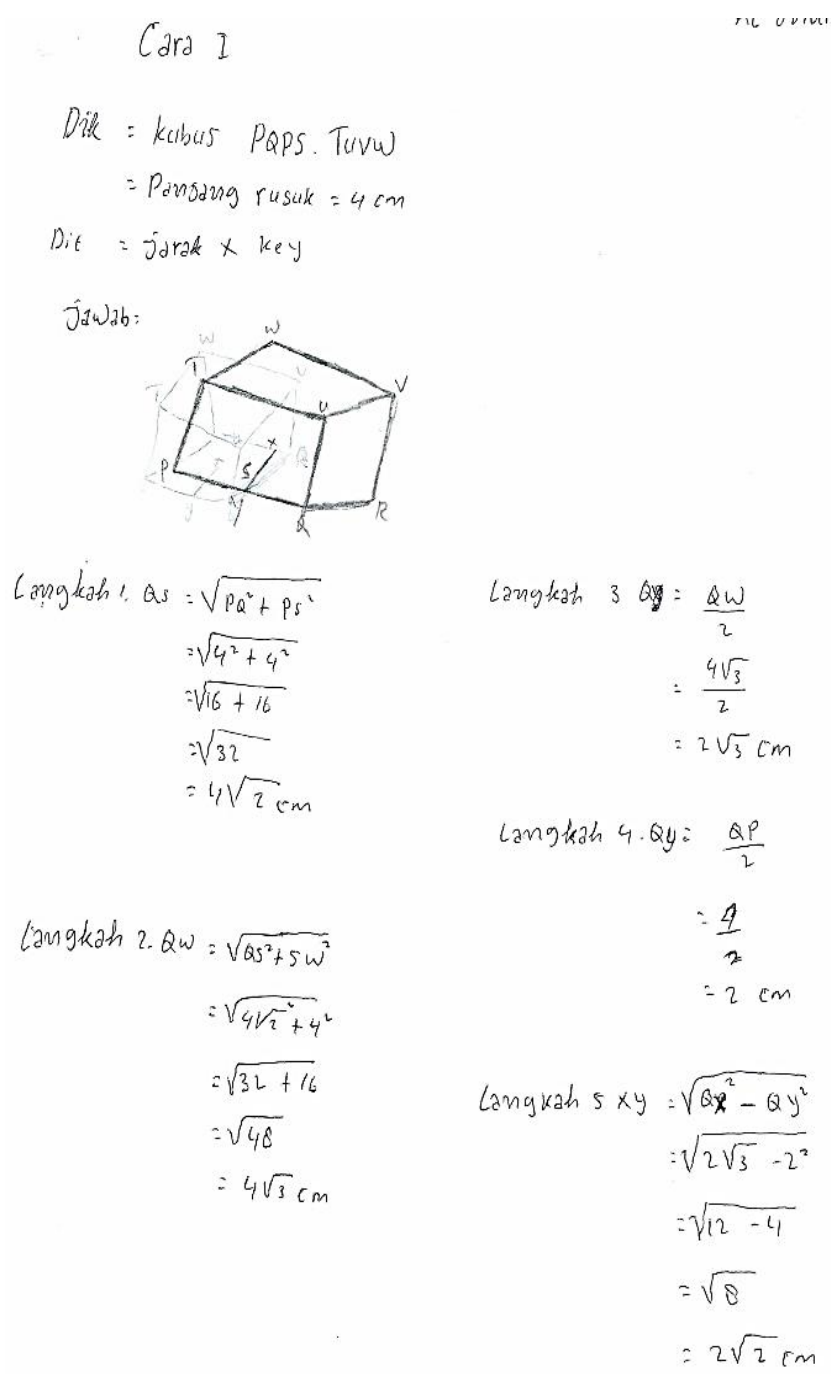

Gambar 12. Cara pertama subjek $C$ pada $T_{1}$

Subjek $C$ telah menuliskan dan dapat menyebutkannya apa yang diketahui dan ditanyakan pada secara lisan. Subjek $C$ juga dapat menyelesaikan permasalahan yang diberikan dengan menggunakan dua cara berbeda, tetapi kedua cara ini termasuk kedalam cara penyelesaian umum atau yang biasa sering digunakan. penyelesaian tidak umum yang telah dikerjakan pada $T_{3}$.

\section{Proses Berpikir Lateral Siswa Berkemampuan Rendah (Subjek $C$ )}

Subjek $C$ telah menuliskan apa yang diketahui dan yang ditanyakan pada soal dan subjek $C$ juga mampu menyelesaikan permasalah pada $T_{1}$ dengan dua cara berbeda. Berikut berikut lembar jawaban $C T_{1}$.

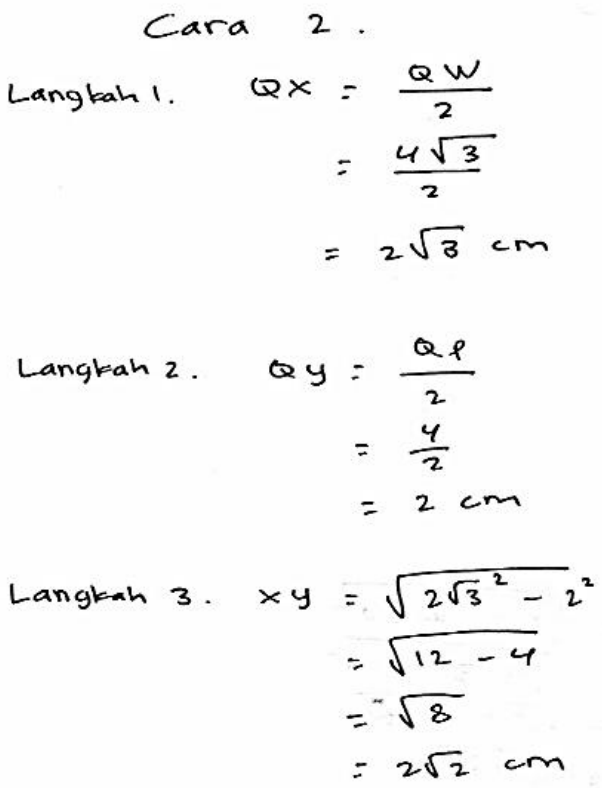

Gambar 13. Cara kedua subjek $C$ pada $T_{1}$

Pada $T_{2}$, subjek $C$ telah menuliskan apa yang diketahui dan yang ditanyakan pada soal dan subjek $C$ juga mampu menyelesaikan permasalah pada $T_{2}$ dengan satu cara. Berikut lembar jawaban $C T_{2}$. 

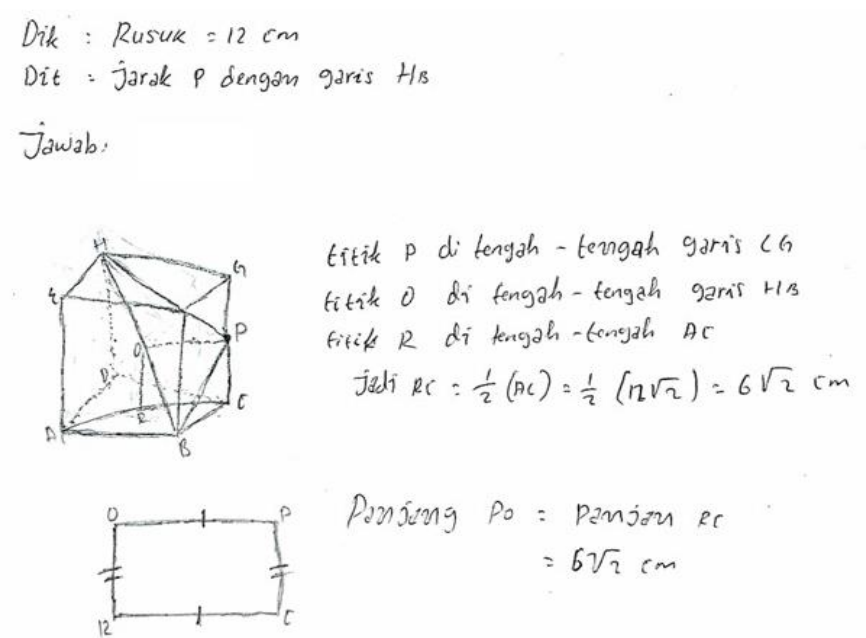

Ponjerng Po = Panjorn RC

$=6 \sqrt{2} \mathrm{~cm}$

Gambar 14. Cara penyelesaian subjek $C$ pada $T_{2}$

Subjek $C$ telah menuliskan dan dapat menyebutkannya apa yang diketahui dan ditanyakan pada secara lisan. Subjek $C$ juga menyelesaikan permasalahan yang diberikan hanya dengan menggunakan satu cara. Cara penyelesaian ini termasuk cara penyelesaian yang tidak umum. Selain itu subjek $C$ juga dapat menjelaskan mengenai ide yang diperoleh dalam menyusun cara menyelesaian yang tidak umum dan juga dapat menjelaskan secara rinci mengenai langkah-langkah penyelesaian tidak umum yang telah dikerjakan pada $T_{2}$.

Pada $T_{3}$, subjek $C$ telah menuliskan apa yang diketahui dan yang ditanyakan pada soal dan subjek $C$ hanya mampu menyelesaikan permasalah pada $T_{3}$ dengan satu cara. Berikut lembar jawaban $C T_{3}$.

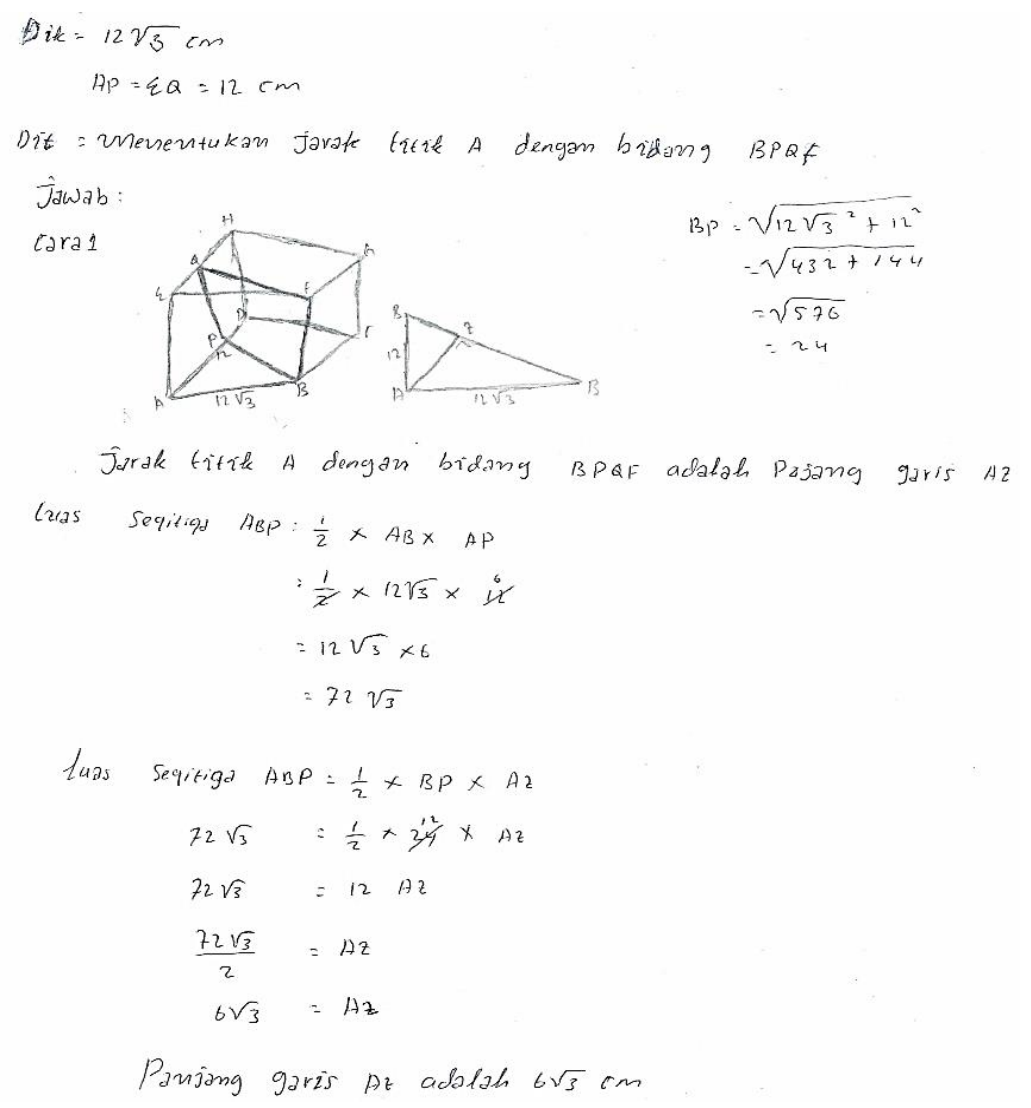

Gambar 15. Cara penyelesaian subjek $C$ pada $T_{3}$ 
Subjek $C$ telah menuliskan dan dapat menyebutkannya apa yang diketahui dan ditanyakan pada secara lisan. Subjek $C$ dapat menyelesaikan permasalahan yang diberikan hanya dengan menggunakan cara cara, tetapi cara ini termasuk kedalam cara penyelesaian umum atau yang biasa sering digunakan.

\section{PEMBAHASAN}

\section{Proses Berpikir Lateral Siswa Berkemampuan Tinggi (Subjek $A$ )}

Dalam mengidentifikasi unsur-unsur yang diketahui pada soal, subjek $A$ terlebih dahulu mencoba untuk memahami permasalahan yang diberikan dengan cara membaca soal tersebut berkali-kali. Setelah memahami permasalahan yang diberikan, subjek $A$ mencoba untuk menuliskan apa yang diketahui dan yang ditanyakan pada soal. Pada permasalahan pertama dan kedua, subjek $A$ tidak menuliskan apa yang diketahui dan yang ditanyakan pada soal dan subjek $A$ tetap dapat menyebutkannya secara lisan. Ini terjadi karena subjek $A$ sudah terbiasa untuk tidak menuliskannya. Sementara untuk permasalahan ketiga, subjek $A$ sudah menuliskan dan menyebutkan apa yang diketahui dan yang ditanyakan pada soal ini secara lengkap.

Dalam memandang permasalahan yang diberikan, subjek $A$ sudah mampu untuk menyelesaikan permasalahan tersebut dengan menggunakan beberapa cara. Pada permasalahan pertama, subjek $A$ sudah dapat menggunakan dua cara penyelesaian. Satu termasuk ke dalam cara penyelesaian yang umum, dan yang satu lagi tidak umum. Pada permasalahan kedua, subjek $A$ juga dapat menggunakan dua cara penyelesaian. Kedua cara ini termasuk ke dalam cara penyelesaian yang tidak umum. Sedangkan untuk permasalah ketiga, subjek $A$ juga menggunakan dua cara penyelesaian. Satu termasuk ke dalam cara penyelesaian yang umum, dan yang satu lagi tidak umum. Semua cara penyelesaian tidak umum ini merupakan hasil karya subjek $A$. Subjek $A$ berusaha mengembangkan sendiri cara penyelesaian tidak umum ini. Ini terjadi karena subjek $A$ mencoba melihat permasalahan melalui sudut pandang yang berbeda.

Dari cara-cara penyelesaian yang telah dikerjakan, subjek $A$ lebih memilih untuk menggunakan cara penyelesaian yang tidak umum. Alasannya karena cara ini lebih singkat, tidak banyak menggunakan perhitungan matematika, dan lebih mudah untuk dipahami. Subjek $A$ juga belum pernah menggunakan cara ini sebelumnya.

Subjek $A$ memiliki ide yang dapat dikembangkan sehingga menghasilkan cara penyelesaian yang tidak umum. Langkahlangkah pada cara penyelesaian tidak umum ini juga terlihat berbeda dari cara biasa (umum). Ide yang muncul pada setiap permasalahan juga berbeda. Pada permasalahan pertama, ide yang muncul berupa hubungan antar garis yang dapat digunakan untuk membuat persegi panjang yang mengakibatkan munculnya sisisisi yang sama panjang. Ide ini muncul secara spontan dengan mencoba-coba. Pada pertemuan kedua, ide yang muncul berupa hubungan garis-garis yang sama panjang (cara penyelesaian pertama) dan hubungan garisgaris sejajar (cara penyelesaian kedua). Ide ini diperoleh dari cara penyelesaian yang pernah dikerjakan sebelumnya (dari permasalahan pertama). Selanjutnya pada pertemuan ketiga, ide yang muncul yaitu menggunakan trigonometri. Ide ini muncul pada saat subjek $A$ melihat ada sebuah sudut siku-siku dengan dua ukuran sisi yang telah diketahui. Dari semua cara penyelesaian tidak umum yang telah digunakan, subjek $A$ juga dapat memberikan penjelasan yang logis mengenai setiap langkah dalam pengerjaannya.

\section{Proses Berpikir Lateral Siswa Berkemampuan Sedang (Subjek B)}

Dalam mengidentifikasi unsur-unsur yang diketahui pada soal, subjek $B$ terlebih dahulu mencoba untuk memahami permasalahan yang diberikan dengan cara membaca soal dan membuat gambar ilustrasi. Setelah memahami permasalahan yang diberikan, subjek $B$ mencoba untuk menuliskan apa yang diketahui dan yang ditanyakan pada soal. Pada permasalahan 
kedua, subjek $B$ tidak menuliskan apa yang diketahui dan yang ditanyakan pada soal dan subjek $B$ tetap dapat menyebutkannya secara lisan. Ini terjadi karena subjek $B$ bekerja dengan terburu-buru sehingga lupa untuk menuliskannya. Sementara untuk permasalahan pertama dan ketiga, subjek $B$ sudah menuliskan dan juga dapat menyebutkan apa yang diketahui dan yang ditanyakan pada soal ini secara lengkap.

Dalam memandang permasalahan yang diberikan, subjek $B$ sudah mampu untuk menyelesaikan permasalahan tersebut dengan menggunakan beberapa cara, kecuali pada permasalahan ketiga. Pada permasalahan pertama, dan kedua subjek $B$ sudah dapat menggunakan dua cara penyelesaian. Satu termasuk ke dalam cara penyelesaian yang umum, dan yang satu lagi tidak umum. Sedangkan untuk permasalah ketiga, subjek $B$ hanya dapat menggunakan satu cara penyelesaian. Cara ini termasuk ke dalam cara penyelesaian yang tidak umum. Pada permasalahan ketiga ini, subjek $B$ mengalami kesulitan dalam mengembangkan cara penyelesaian lain.

Dari semua cara penyelesaian yang telah dikerjakan, subjek $B$ lebih memilih menggunakan cara penyelesaian yan tidak umum. Alasannya karena cara ini lebih singkat, dan mudah untuk dipahami. Subjek $B$ juga belum pernah menggunakan cara ini sebelumnya.

Subjek $B$ memiliki ide yang dapat dikembangkan sendiri sehingga menghasilkan cara penyelesaian yang tidak umum. Langkahlangkah pada cara penyelesaian tidak umum ini juga terlihat berbeda dari cara biasa (umum). Ide yang muncul pada setiap permasalahan juga berbeda. Pada permasalahan pertama, ide yang muncul yaitu mencoba membuat sebuah bidang diagonal yang bertujuan untuk menentukan garis lain yang panjangnya sama dengan XY. Pada pertemuan kedua, ide yang muncul berupa membuat hubungan antara garis PQ dengan diangonal AC. Sedangkan pada permasalahan ketiga, menggunakan trigonometri dengan memanfaatkan segitiga siku-siku. Keseluruhan ide ini muncul dengan cara mencoba-coba.

\section{Proses Berpikir Lateral Siswa Berkemampuan Rendah (Subjek $C$ )}

Dalam mengidentifikasi unsur-unsur yang diketahui pada soal, subjek $C$ terlebih dahulu mencoba untuk memahami permasalahan yang diberikan dengan cara membaca soal tersebut berkali-kali. Setelah memahami permasalahan yang diberikan, subjek $C$ melanjutkan dengan menuliskan apa yang diketahui dan yang ditanyakan pada soal. Untuk setiap permasalahan yang diberikan, subjek $C$ selalu menuliskan apa yang diketahui dan yang ditanyakan pada soal. Subjek $C$ juga dapat menyebutkan apa yang diketahui dan yang ditanyakan ini dengan lisan secara lengkap.

Setelah memahami permasalahan yang diberikan, subjek $C$ mencoba untuk menyelesaikan permasalahan dengan beberapa cara. Dari semua permasalahan yang diberikan, hanya pada permasalahan pertama subjek $C$ dapat menyelesaikan dengan menggunakan dua cara. Kedua cara ini pun terlihat sama, hanya saja langkah penyelesaian pada cara kedua lebih singkat dari cara pertama. Ini terjadi karena subjek $C$ mencoba untuk mempersingkat langkah-langkah penyelesaian pada cara kedua. Pada permasalahan kedua dan ketiga, subjek $C$ hanya dapat menggunakan satu cara untuk menyelesaikan permasalahan.

Dari seluruh cara penyelesaian yang digunakan, subjek $C$ hanya dapat mengembangkan satu cara penyelesaian tidak umum. Cara ini digunakan untuk menyelesaikan permasalahan kedua. Subjek $C$ menggunakan cara ini karena menganggap cara ini sudah dipahami.

Subjek $C$ mendapatkan sebuah ide yang dapat dikembangkan sehingga menghasilkan sebuah cara penyelesaian tidak umum yang dapat digunakan dalam menyelesaikan permasalah kedua. Ide yang muncul yaitu mencoba memanfaatkan diagonal AC. Melalui diagonal AC inilah subjek $C$ ini dapat menentukan jarak titik P ke garis HB. Subjek $C$ juga dapat memberikan penjelasan yang baik mengenai langkah-langkah pada cara penyelesaian yang tidak umum ini. 


\section{PENUTUP}

Berdasarkan pembahasan yang telah diuraikan sebelumnya, dapat ditarik kesimpulan bahwa proses berpikir lateral siswa adalah (1) Menuliskan dan menyebutkan apa yang diketahui dan yang ditanyakan pada soal; (2) Menyelesaikan permasalahan yang diberikan dengan mengunakan cara-cara penyelesaian berbeda (3) Menyelesaikan permasalahan dengan menggunakan cara yang tidak umum, lebih memilih menggunakan cara penyelesaiaan tidak umum karena relatif lebih singkat, tidak banyak menggunakan perhitungan matematika, dan mudah dipahami, dan; (4) Mendapatkan ide dalam menyelesaikan permasalahan dengan cara mencoba-coba, memanfaatkan cara penyelesaian yang pernah dikerjakan sebelumnya, memanfaatkan segitiga siku-siku, diagonal garis, dan mampu memberikan penjelasan mengenai langkah penyelesaian tidak umum yang telah digunakan.

Berdasarkan simpulan di atas, maka disarankan dalam pembelajaran matematika, guru hendaknya dapat melatih dan membiasakan siswa untuk berpikir lateral dengan menggunakan soal-soal berbentuk open-ended. Bagi peneliti lain yang hendak melakukan penelitian yang relevan dengan penelitian ini, hendaknya mempertimbangkan kualitas sekolah yang akan diteliti agar hasil yang diperoleh dapat lebih maksimal.

\section{UCAPAN TERIMA KASIH}

Terima kasih kepada Kepala Madrasah dan Para Guru Bidang Studi Pendidikan Matematika Madrasah Aliyah Swasta Darul Hikmah Aceh Besar. Pihak madrasah telah memberikan kesempatan kepada peneliti untuk mengembangkan tulisan dalam bentuk artikel penelitian ini sebagai salah satu persyaratan kelulusan Program Pascasarjana Magister Pendidikan Matematika FKIP Unsyiah.

\section{DAFTAR PUSTAKA}

Becker, J. P., \& Shimada, S. (2005). The Open-Ended Approach: A New Proposal for Teaching. Reston: National Council of Teachers of Mathematic (NCTM).
Bobango, J. C. (1993). Geometry for All Student: Phase-Based Instruction. Dalam Cuevas (Eds). Reaching All Students With Mathematics. Virginia: The National Council of Teachers of Mathematics, Inc.

Bono, E. D. (1991). Penerapan Pola Berpikir Lateral (terjemahan. Dandan Riskomar ) Jakarta: Binarupa Aksara.

Bono, E. D. (1992). Serious Creativity Using The Power of Lateral Tinking to Create New Ideas. New York: Harper Business.

Direktorat Jenderal Pendidikan Islam Kementrian Agama RI. (14 Desember 2018). Visi, Misi dan Tujuan Pendidikan Islam 2015-2019, http://pendis.kemenag.go.id/index.php?a $=$ artikel\&id $2=$ visimisipendis .

Jazuli, A. (2009). Jigsaw Type of Cooperative Learning as a Means of Improving High School-Students' Mathematical Communication Ability. EDUCARE, 1(2) 207-218.

Miles, M. B., \& Huberman A, M. (1994). Qualilative Data Analysis: Second Edition. United States of America: Sage Publications.

Moleong, L. J. (2016). Metodologi Penelitian Kualitatif. Edisi Revisi. Bandung: PT Remaja Rosdakarya.

Muliawati, N. E. (2017). Proses Berpikir Lateral Siswa dalam Memecahkan Masalah Berdasarkan Gaya Kognitif dan Gender. Jurnal Pendidikan dan Pembelajaran Matematika (JP2M), 2(1), 55-68.

Munandar, S. C. U. (1992). Mengembangkan Bakat dan Kreativitas Anak Sekolah: Petunjuk Bagi Para Guru dan Orang Tua. Jakarta: PT Gramedia.

National Council of Teachers of Mathematic. (2000). Principle and Standards for School Mathematics. USA: NCTM. 
Ngilawajan, D, A. (2013). Proses Berpikir Siswa SMA dalam Memecahkan Masalah Matematika Materi Turunan Ditinjau dari Gaya Kognitif Field Independent dan Field Dependent. PEDAGOGIA, 1(1), 71-83.

Nurhasanah, F. (2010). Abstraksi Siswa SMP dalam Belajar Geometri melalui Penerapan Model Van Hiele dan Geometers Sketchpad. Thesis, Universitas Pendidikan Indonesia.

Nurhidayah, S. D. (2016). Meningkatkan Kemampuan Berpikir Lateral Matematis Siswa melalui Pendekatan Open-Ended. Thesis, Universitas Pendidikan Indonesia.

Puspitarini, M. (9 September 2015). Ini penyebab Nilai Matematika Indonesia Rendah, https://news.okezone.com/read/2014/09/ 09/373/1036506/ini-penyebab-nilaimatematika-indonesia-rendah.

Rosnawati, R. (2011). Berpikir Lateral Dalam Pembelajaran Matematika. Prosiding Seminar Nasional Penelitian, Pendidikan dan Penerapan MIPA, 139-144. Fakultas MIPA, Universitas Negeri Yogyakarta: Prosiding Seminar Nasional Penelitian, Pendidikan dan Penerapan MIPA.

Sa'diyah, H. (2016). Profil Berpikir Lateral dalam Menyelesaikan Masalah Matematika Materi Bangun Datar pada Siswa Kelas IX di Smp Negeri 1 Sidoarjo. Thesis, UIN Sunan Ampel Surabaya.
Sloane, P. (1994). Test Your Lateral Thinking $I Q$. New York: Sterling Publishing Company, Inc.

Soedjadi. (2000). Kiat Pendidikan Matematika di Indonesia. Jakarta: Direktorat Jendral Pendidikan Tinggi Departemen Pendidikan Nasional.

Suherman, E., Turmudi., Suryadi, D., Herman, T., Suhendra., Prabawanto, S., Nurjanah., \& Rohayati, A. (2003). Strategi Pembelajaran Matematika Kontemporer. Bandung: Jurusan Pendidikan Matematika Fakultas Pendidikan Matematika dan Ilmu Pendidikan Alam Universitas Pendidikan Indonesia.

Suprapti, W. (2015). Bahan Ajar Diklat Kepemimpinan Tingkat 3: Agenda Inovasi. Lembaga Administrasi Negara Republik Indonesia: Jakarta

Syutaridho. (2012). Berpikir Lateral dalam Matematika. ISSN 2089-8703, 1(1), 2229.

TIM PUSPENDIK. (2012). Kemampuan Matematika Siswa SMP Indonesia: Menurut Bebchmark Internasional TIMSS 2011. Pusat Penelitian Pendidikan Badan Penelitian dan Pengembangan Kementrian Pendidikan dan Kebudayaan: Jakarta.

Waks, S. (1997). Lateral Thinking and Technology Education. Journal of Science Education and Technology, 6(4), 245-255.

Yulaelawati, E. (2004). Kurikulum dan Pembelajaran. Bandung: Pakar Raya. 